\title{
Associations between night eating syndrome and metabolic parameters in pregnant women
}

\section{Gebelerde gece yeme sendromu ve metabolik parametreler arasindaki ilişki}

\author{
(1) Çiğdem Damla Deniz¹, (1) Sibel Özler², (1) Fatma Kübra Sayın³, (1) Mehmet Ali Eryılmaz ${ }^{4}$ \\ ${ }^{1}$ University of Health Sciences, Konya Training and Research Hospital, Clinic of Medical Biochemistry Konya, Turkey \\ 2 University of Health Sciences, Konya Training and Research Hospital, Clinic of Perinatalogy, Konya, Turkey \\ ${ }^{3}$ Necmettin Erbakan University, Faculty of Health Sciences, Department of Nutrition and Dietetics, Konya, Turkey \\ ${ }^{4}$ University of Health Sciences, Konya Training and Research Hospital, Clinic General Surgery, Konya, Turkey
}

\begin{abstract}
Objective: In this study, we aimed to evaluate the incidence of night eating in pregnancy and the relationship between night eating scores and nutritional status, insulin resistance, and lipid profile in pregnant women.

Materials and Methods: In this study, 148 pregnant women who presented to the Gynecology and Obstetrics Clinics at Konya Training and Research Hospital in Konya were divided into two groups according to their night eating scores. These two groups were compared in terms of their nutritional attitudes and metabolic parameters.

Results: Comparisons of participants meeting night eating syndrome (NES) scores versus women without NES indicated that patients with NES exhibited fever hunger at breakfast time, more breakfast skipping $(\mathrm{p}<0.05)$ than those without NES. Also homeostatic model assessment insulin resistance, insulin, and high-density lipoprotein cholesterol parameters were significantly higher in pregnant women in the NES group (p<0.05). Also, correlations were found between higher night eating questionnaire total scores and higher HbAlc, insulin resistance, insulin, and more breakfast skipping.

Conclusion: The results of this study suggest that night eating symptoms during pregnancy may increase and this is able to effect glucose metabolism. Keywords: Night eating syndrome, pregnancy, metabolic parameters in pregnancy

$\ddot{\mathrm{O} z}$

Amaç: Bu çalışmada, gebe kadınlarda gece yeme insidansını belirlemeyi ve gece yeme skorları ile beslenme durumu, insülin direnci ve lipit profili arasındaki ilişkiyi değerlendirmeyi amaçladık.

Gereç ve Yöntemler: Bu çalışmada Konya Eğitim ve Araştırma Hastanesi Kadın Hastalıkları ve Doğum Kliniği'ne başvuran 148 gebe gece yeme puanlarına göre iki gruba ayrıldı. Bu iki grup, beslenme tutumları ve metabolik parametreleri açısından karşılaştırıldı.

Bulgular: Gece yeme sendromu ölçütlerini karşılayan katılımcıların karşılamayanlara göre kahvaltı saatlerinde daha az aç hissettiklerini, fazla kahvaltı atladıklarını $(\mathrm{p}<0,05)$ göstermiştir. Ayrıca gece yeme skorları yüksek gebelerde insülin direncinin homeostatik model değerlendirmesi, insülin ve yüksek yoğunluklu lipoprotein kolesterol parametreleri anlamlı olarak yüksek bulundu ( $<<0,05)$. Ayrıca yüksek gece yeme ölçeği toplam skorları ile daha yüksek HbAlc, insülin direnci, insülin ve kahvaltı ögününü atlaması arasında korelasyon bulundu.

Sonuç: Bu çalışmanın sonuçları gebelik sırasında gece yeme semptomlarının artabileceğini ve bunun glikoz metabolizmasını etkileyebileceğini düşündürmektedir.
\end{abstract}

Anahtar Kelimeler: Gece yeme sendromu, gebelik, gebelikte metabolik belirteçler

PRECIS: There is an increase in night eating symptoms during pregnancy and this is able to affect glucose metabolism.

Address for Correspondence/Yazışma Adresi: Fatma Kübra Sayın, MD,

Necmettin Erbakan University, Faculty of Health Sciences, Department of Nutrition and Dietetics, Konya, Turkey

E-mail: kubrakucur@hotmail.com ORCID ID: orcid.org/0000-0002-6052-4645

Received/Geliș Tarihi: 27.11.2018 Accepted/Kabul Tarihi: 01.04.2019

${ }^{\oplus}$ Copyright 2019 by Turkish Society of Obstetrics and Gynecology

Turkish Journal of Obstetrics and Gynecology published by Galenos Publishing House 


\section{Introduction}

Night eating syndrome (NES) is a disorder characterized by evening hyperphagia and nocturnal ingestion, in addition to sleep and mood disturbances ${ }^{(1)}$. Evening hyperphagia is generally defined as the consumption of more than $25 \%$ of the daily calories after dinner ${ }^{(2)}$. In addition to these symptoms, patients may experience insomnia, a severe urge to eat at night, with morning anorexia or breakfast skipping ${ }^{(3)}$. For this reason, eating at night is a complex syndrome involving poor nutrition, disordered sleep patterns, and depressed mood. NES has been found associated with eating disorder (ED) attitudes and poor physical and psychosocial functioning ${ }^{(3-6)}$. Furthermore, people with NES have a relatively high risk of obesity, inadequate glycemic control (HbAlc values $>7 \%$ ), and having two or more diabetic complications ${ }^{(7)}$. The prevalence of NES in the adult population was reported as $1-1.5 \%$. Although this syndrome is seen in non-obese subjects, it is more prevalent among obese individuals (6-42\%), especially for attenuation therapy ${ }^{(4,8,9)}$.

Pregnancy can lead to an increase in night eating due to both the effect of metabolic changes and disturbed sleep patterns. Healthy nutrition and weight control knowledge during pregnancy have a great effect on the prevention of pregnancy complications. The detection of night eating problems in pregnant women is important for preventing health problems that many pregnant women and babies will be exposed to. This is the first study to highlight the relationship between NES and metabolic problems such as insulin resistance and lipid profile in pregnant women. Determining this relationship is important for preventive medicine. Thus, the aims of this study were to determine the incidence of night eating in pregnancy, and to determine the relationship between night eating scores and insulin resistance, lipid profile, and nutritional status in pregnant women.

\section{Materials and Methods}

\section{Participants and procedure}

A total of 148 women with singleton pregnancies were recruited from Gynecology and Obstetrics Clinics at Konya Training and Research Hospital in during their medical appointments between June 2017 and June 2018. They were at least 18 years of age. Pregnant women who were on chemotherapy or psychotropic drugs or who had diabetes mellitus were excluded from the study. All participants gave written informed consent. This study was conducted according to the guidelines laid down in the Declaration of Helsinki. Ethical approval was obtained from the Necmettin Erbakan Univercity Medical Faculty Ethics Committee Review Board (approval no: 2017/1066).

\section{Measures}

Interviews and measurements were conducted in the clinics at recruitment and at 28-38 weeks' gestation. Data on hunger scores in the morning and at night before sleep, breakfast skipping, and night eating scores were collected.

Hunger scores in the morning and at night during pregnancy were assessed using structured interviewer-administered questions: hunger scores were assessed by asking the question "How much do you feel hungry when you wake up?" The women were asked to choose one of 6 scores: 1) Empty; weak and light-headed. Your body is begging for food and you start to feel dizzy and nauseous. 2) Over-hungry. You feel irritable and unable to concentrate. You may even feel nauseous. 3) Hunger awakens. Slightly uncomfortable. You are just beginning to feel signs of hunger. Your body is giving you the signal that you might want to eat. 4) Neutral/ comfortable. You are more or less satisfied, but could eat a little more. Your body has enough fuel to keep it going and is physically and psychologically just starting to feel satisfied. 5) Completely satisfied. A little bit uncomfortable. You are past the point of satisfaction, yet you can still "find room" for a little more. Your body says "no" and your mind says "yes" to a few more bites. 6) Stuffed. Very uncomfortably full. You feel heavy, tired, and bloated. Higher scores reflect feeling more full.

For determining the NES, the Night Eating Questionnaire $(\mathrm{NEQ})^{(10)}$ was used. Atasoy et al., ${ }^{(1)}$ evaluated the reliability and validity of Turkish version of the NEQ. The NEQ is a 14item self-report measure of NES that results in a total score with higher scores reflecting greater night eating pathologies. One item, item 13, does not assess NES pathology, but rather is used as a rule-out for sleep-related ED, and it is therefore not included in the total score calculation. A cut-off of 25 has been used to screen for NES using this measure ${ }^{(10)}$. In the standardization samples, the mean total scores on the NEQ were 32.4 [standard deviation (SD): 6.8] for patients with NES and 16.0 (SD: 6.3) for patients with obesity without NES who presented for bariatric surgery. The NEQ is composed of four factors (nocturnal ingestions, evening hyperphagia, morning anorexia, and sleep/mood). Each factor is represented by three items, with the exception of the nocturnal ingestions factor, which has five items. Each item has five response options, which are coded from 0 to 4 , with higher scores reflecting greater impairment.

The weight and health status of the newborns were obtained from the medical charts of infants.

\section{Blood sample analysis}

The analyses were performed in the Clinic of Biochemistry, Konya Training and Research Hospital. The plasma concentrations of the following parameters were analyzed: fasting glucose, fasting insulin, hemoglobin Alc, lipid profile, hemogram, and vitamin D. Insulin resistance, estimated by the homeostatic model assessment-method (HOMA-IR) for glucose metabolism, serum total cholesterol, low-density lipoprotein cholesterol (LDL-C), and high-density lipoprotein cholesterol (HDL-C) for lipid metabolism. 
Insulin concentrations were measured using a chemiluminescent method with a Siemens immulite 2000 xPi immunoassay analyzer (Siemens Inc.). Serum glucose and lipid concentrations were analyzed with Beckman Kits using Beckman Coulter AU 5800 biochemical analyzer (Beckman Coulter, Inc., USA). Glucose was measured using a glucose6-phosphate dehydrogenase enzymatic assay. Triglycerides, total cholesterol, and HDL-C concentrations were determined using enzymatic colorimetry. LDL cholesterol was calculated using the Friedewald equation.

Vitamin D was analyzed using an automatic immunoassay with an Abbott Kits (Abbott Laboratories, IL 60064, USA) on architect plus i2000SR analyzer. HbAlc was determined using high-performance liquid chromatography (Trinity Biotech Premier 9210, USA).

\section{Statistical Analysis}

All statistical analyses were performed using the SPSS version 16.0 software (IBM, Chicago, IL). The Mann-Whitney U test was used to compare the related blood parameters between the non-NES and NES group. Spearman correlations were used to determine the correlation between the night eating score with demographic, glucose metabolism, and lipid metabolism parameters. $\mathrm{P}<0.05$ was considered statistically significant.

\section{Results}

\section{Characteristics of the participants}

A sample of 148 pregnant women (mean age 28.4 years, SD: 5.88 , range $18-44$ years) were included in this study. The average body mass index (BMI) was $30.66 \mathrm{~kg} / \mathrm{m}^{2}$ (SD: 4.42 , range $24.26-40.00 \mathrm{~kg} / \mathrm{m}^{2}$ ).

The mean hunger score in the morning before breakfast was 2.75 (SD: 1.87), and 15\% of participants scored more then 4 , which means really full. The mean night hunger score was 3.61 (SD: 2.11), and 36\% of participants scored more then 4 , meaning that they were really full.

No significant differences in maternal characteristics were observed for age, BMI, and night eating score between women with and without NES (all $\mathrm{p} \geq 0.05$ ). Morning hunger scores and breakfast skipping were significantly higher in the NES group compared with the non-NES group.

The mean score on the NEQ was 16.53 (SD: 5.88, range: $5-35)$ using a cut-off of 25 on the NEQ; ${ }^{(12)} 11.48 \%(n=17)$ of the participants met the criteria for NES. The means of the NES and non-NES group scores were 32.21 (SD: 5.52, range: 25-35) and 14.51 (SD: 4.78, range: 5-24), respectively.

\section{Comparison between NES and non-NES}

Comparisons of participants meeting NES criteria versus those who did not meet the criteria (Table 1) indicated that patients with NES exhibited fever hunger at breakfast time, and more breakfast skipping than pregnant women without
NES ( $\mathrm{p}<0.05)$. Also HOMA-IR, insulin, TC, and HDL-C parameters were significantly higher in pregnant women in the NES group $(p<0.05)$. Fetal weights of the NES group were heavier than in the non-NES group, but the difference was not significant.

\section{Correlations with night eating}

Correlations between night eating with lipid profile, vitamin $\mathrm{D}$, and glucose metabolism variables are described in Table 2. Significant small to large correlations were found between higher NEQ total scores and higher $\mathrm{HbAlc}$, insulin resistance, insulin, more breakfast skipping, and feeling full before breakfast.

\section{Discussion}

This study investigated the prevalence of night eating in the third timester of pregnancy, and also determined the relationships among night eating symptoms and relevant metabolic variables in this population.

In this study, $11.5 \%$ of participants met the screening criteria for NES, which were determined using the NEQ. As expected, the mean score in our study was higher than the mean scores

Table 1. Comparison between pregnants with and without NES

\begin{tabular}{|c|c|c|c|}
\hline & NES $(n=17)$ & $\begin{array}{l}\text { Non-NES } \\
(n=131)\end{array}$ & $\begin{array}{l}\mathrm{p} \\
\text { value }\end{array}$ \\
\hline Age (years) & $27.39(4.81)$ & $29.08(6.76)$ & 0.205 \\
\hline $\mathrm{BMI}\left(\mathrm{kg} / \mathrm{m}^{2}\right)$ & $29.56(4.41)$ & $30.87(4.39)$ & 0.288 \\
\hline NE score & $32.21(5.52)$ & $14.51(4.78)$ & $<0.001$ \\
\hline $\begin{array}{l}\text { Morning hunger } \\
\text { score }\end{array}$ & $2.77(0.82)$ & $2.50(0.67)$ & 0.042 \\
\hline Night hunger score & $3.80(0.94)$ & $3.36(1.21)$ & 0.069 \\
\hline $\begin{array}{l}\text { Skipping breakfast } \\
\text { (day in a week) }\end{array}$ & $4.38(2.98)$ & $2.98(2.35)$ & 0.003 \\
\hline \multicolumn{4}{|l|}{ Glucose metabolism } \\
\hline Insulin (mIU/L) & $9.74(5.50)$ & $6.97(4.78)$ & 0.012 \\
\hline Glucose (mg/dL) & $89.08(11.96)$ & $84.99(10.72)$ & 0.083 \\
\hline HOMA-IR & $2.98(2.27)$ & $1.60(1.46)$ & 0.001 \\
\hline HbAlc（\%） & $5.38(0.39)$ & $5.47(0.43)$ & 0.234 \\
\hline \multicolumn{4}{|l|}{ Lipid metabolism } \\
\hline TC (mg/dL) & $272.70(45.87)$ & $252.62(47.20)$ & 0.031 \\
\hline LDL (mg/dL) & $152.39(41.22)$ & $144.63(36.98)$ & 0.321 \\
\hline HDL (mg/dL) & $66.78(10.44)$ & $61.66(13.01)$ & 0.021 \\
\hline Vitamin D ( $\mu \mathrm{g} / \mathrm{L})$ & $13.10(9.22)$ & $12.18(8.89)$ & 0.648 \\
\hline Fetal weight (g) & $3197.3(389.11)$ & $3364(588.31)$ & 0.098 \\
\hline
\end{tabular}


of $4.5 \%$ and $4.6 \%$ in the healthy control studies. Other studies that used the NEQ as the measure of night eating in patients with diabetes found prevalence of NES as $7 \%, 8.4 \%$, and $9.7 \%^{(13-15)}$. NES is a relatively common problem in morbidly obese individuals, and a definite diagnosis of NES was present in $10 \%$ of the obese group ${ }^{(16)}$. The wide range of prevalences reported across studies can be explain by the difference of assessment methods and the differences between participants in the groups. This study shows that pregnant women may have an increased tendency to night eating.

In regard to eating habits, the results indicated that increased night eating was associated with decreased morning hunger and increased breakfast skipping. This is consistent with a study of patients with diabetes that found increased breakfast skipping in patients with NES ${ }^{(14)}$.

According to our results in pregnant women, increased night eating scores are associated with increased insulin resistance. This is consistent with studies of patients with diabetes that found that increased NES was associated with poorer glycemic control ${ }^{(7,14,16)}$. Evidence of the relationship between night eating and glycemic control is mixed, possibly due to differences in symptom measurement and study samples. For example, Allison et al., ${ }^{(12)}$ measured night eating symptoms

Table 2. Correlations with NES

\begin{tabular}{lll} 
& $\begin{array}{l}\text { NE score } \\
\text { correlation }\end{array}$ & \\
& P \\
& coefficient & \\
\hline Age (years) & -0.055 & 0.521 \\
\hline BMI (kg/m²) & 0.036 & 0.673 \\
\hline Morning hunger score & -0.235 & 0.006 \\
\hline Night hunger score & 0.181 & 0.037 \\
\hline Skipping breakfast (day in a week) & 0.201 & 0.012 \\
\hline Glucose metabolism & & \\
\hline Insulin (mIU/L) & 0.289 & 0.001 \\
\hline Glucose (mmol/L) & 0.054 & 0.530 \\
\hline HOMA-IR & 0.261 & 0.002 \\
\hline HbAlc (\%) & 0.167 & 0.048 \\
\hline Lipid metabolism & & \\
\hline TC (mg/dL) & -0.027 & 0.711 \\
\hline LDL (mg/dL) & 140 & 0.123 \\
\hline HDL (mg/dL) & 0.120 & 0.156 \\
\hline Hemogram & 0.031 & 0.718 \\
\hline Vitamin D ( $\mu$ g/L) & 0.185 & 0.028 \\
\hline Fetal weight (g) & 0.034 & 0.690 \\
\hline TC: Total cholesterol, HOMA-IR: Homeostatic model assessment insulin resistance, LDL: & \\
\hline Body mass index, NES: Night eating syndrome NE: Night eating & \\
\hline
\end{tabular}

using the NEQ and found no difference in $\mathrm{HbAlc}$ values in the NES and non-NES groups. However, in another study, Loy et al., (17) showed that increased night hunger and a reduced number of meals in the second trimester of pregnancy resulted in a decrease in fasting blood glucose and $2^{\text {nd }}$ hour of postprandial glucose. It has been observed that fasting for 10 hours in the control of the gestational glycemia is effective ${ }^{(18)}$. Gestational hyperglycemia contributes to a long-term risk for obesity in childhood, ${ }^{(19)}$ neonatal adiposity, and negative perinatal outcomes ${ }^{(20)}$. These risks occur even at blood glucose concentrations below the diagnostic limit for gestational diabetes mellitus. There is evidence that moderate glycemic recovery improves perinatal outcomes in pregnant women with mild glucose intolerance ${ }^{(21)}$. To date, dietary approaches to glycemic control have mostly focused on dietary quantity and quality. However, keeping the eating time range within certain limits may offer an innovative and feasible strategy to prevent gestational hyperglycemia ${ }^{(22)}$. Night-eating behavior can harm glycemic control, sleep patterns, and weight control in pregnant women ${ }^{(23)}$.

Our data confirm no association between NES and BMI in pregnant women. In a cross-sectional study of participants with diabetes, participants with NES had higher BMI and they were more likely to have unsatisfactory metabolic control. This evidence does not hold true in the obese population; Calugi et al., ${ }^{(16)}$ found no differences in the prevalence of the metabolic syndrome and in its individual components between participants with and without NES. The prevalence of metabolic syndrome in the obese population is already high, so it is difficult to implicate an additional effect of NES. EDs affect about 5-7\% of women of chilbearing age. Previous studies have shown that the effect of pregnancy on ED symptoms largely remains unclear. Eating behavior in women with a history of anorexia nervosa may improve with pregnancy but appears to revert to prepregnancy concentrations $^{(24)}$. Bulimia nevrosa symptoms during pregnancy have shown mixed results, there is evidence for worsening, ${ }^{(25)}$ but also for improvement of bulimia nevrosa symptoms during pregnancy ${ }^{(26,27)}$. A study of Crow et al., ${ }^{(28)}$ showed that pregnancy had an improving effect on binge eating and purging in women who had had eating desorders before pregnancy. In another study, the proportion of women meeting criteria for binge ED was found to increase during pregnancy.

\section{Study Limitations}

The literature is limited to EDs such as anorexia, bulimia, and binge eating. In our study, it is seen that NES does not tend to improve in pregnancy in contrast to other EDs.

\section{Conclusion}

To our knowledge, no studies of night eating symptoms during pregnancy have been conducted. The results of this 
study suggest that night eating symptoms during pregnancy may increase and this is able to affect glucose metabolism. Our findings can be evaluated as follows: pregnancy can lead to changes in eating attitudes and behaviors, even in women without EDs. Future research in this area should use larger samples to examine the possibility of metabolic effects of NE symptoms during pregnancy.

\section{Ethics}

Ethics Committee Approval: Approval for the study was by the Necmettin Erbakan University Faculty of Medicine Ethics Committee (approval no: 2017/1066), and all procedures were performed in accordance with the Helsinki Declaration. Informed Consent: Informed consent was obtained from all study participants.

Peer-review: External and internal peer-reviewed.

\section{Authorship Contributions}

Surgical and Medical Practices: S.Ö., Concept: F.K.S., C.D.D., S.Ö., Design: F.K.S., M.A.E., Data Collection or Processing: S.Ö., C.D.D., Analysis or Interpretation: F.K.S., C.D.D., Literature Search: C.D.D., M.A.E., Writing: F.K.S., C.D.D.

Conflict of Interest: No conflict of interest was declared by the authors.

Financial Disclosure: The authors declared that this study received no financial support.

\section{References}

1. Herpertz-Dahlmann B. Adolescent eating disorders: definitions, symptomatology, epidemiology and comorbidity. Child Adolesc Psychiatr Clin N Am 2009;18:31-47.

2. Allison KC, Lundgren JD, O'Reardon JP, Geliebter A, Gluck ME, Vinai P, et al. Proposed diagnostic criteria for night eating syndrome. Int J Eat Disord 2010;243:241-7.

3. Vinai P, Allison KC, Cardetti S, Carpegna G, Ferrato N, Masante D, et al. Psychopathology and treatment of night eating syndrome: a review. Eat Weight Disord 2008;13:54-63.

4. Fischer S, Meyer AH, Hermann E, Tuch A, Munsch S. Night eating syndrome in young adults: delineation from other eating disorders and clinical significance. Psychiatry Res 2012;200:494-501.

5. Nolan LJ, Geliebter A. Night eating is associated with emotional and external eating in college students. Eat Behav 2012;13:202-6.

6. Thompson SH, DeBate RD. An exploratory study of the relationship between night eating syndrome and depression among college students. J Coll Stud Psychotherapy 2010;24:39-48.

7. Morse S, KatonWJ, Ciechanowski PS, Hirsch IB. Isn't this just bedtime snacking? Diabetes Care 2006;29:1800-4.

8. Cerú-Björk C, Andersson I, Rössner S. Night eating and nocturnal eatingtwo different or similar syndrom esamongobese patients? Int J Obes Relat Metab Disord 2001;3:365-72.

9. Allison KC, Wadden TA, Sarwer DB, Fabricatore AN, Crerand CE, Gibbons LM, et al. Night eating syndrome and binge eating disorder among persons seeking bariatric surgery: Prevalence and related features. Obesity 2006;14:77-82.

10. Allison KC, Lundgren JD, O'Reardon JP, Martino NS, Sarwer DB, Wadden TA, et al. The night eating questionnaire (NEQ): psychometric properties of a measure of severity of the Night Eating Syndrome. Eat Behav 2008;9:62-72.

11. Atasoy N, Saraçlı Ö, Konuk N, Ankaralı H, Güriz SO, Akdemir A, et al. The reliability and validity of Turkish version of the night eating questionnaire in psychiatric outpatient population. Anatolian Journal of Psychiatry 2014;15:238-47.

12. Allison KC, Crow SJ, Reeves RR, West DS, Foreyt JP, DiLillo VG, et al. Binge eating disorder and night eating syndrome in adults with type 2 diabetes. Obesity 2007;15:1287-93.

13. Rand CS, Macgregor AM, Stunkard AJ. The night eating syndrome in the general population and among post-operative obesity surgery patients. Int J Eat Disord 1997;22:65-9.

14. Marshall HM, Allison KC, O'Reardon JP, Birketvedt G, Stunkard AJ. The night eating syndrome among nonobese persons. Int J Eat Disord 2004;35:217-22.

15. Hood MM, Reutrakul S, Crowley SJ. Night eating in patients with type 2 diabetes. Associations withglycemic control, eating patterns, sleep, and mood. Appetite 2014;79:91-6.

16. Calugi S, Grave RD, Marchesini G. Night eating syndrome in class II-III obesity: metabolic and psychopathological features. Int J Obes (Lond) 2009;33:899-904.

17. Loy SL, Chan YKC, Wee PH, Colega MT, Cheung YB, Godfrey KM, et al. Maternal circadian eating time and frequency are associated with blood glucose concentrations during pregnancy. J Nutr 2017;147:70-7.

18. Chong MF, Chia AR, Colega M, Tint MT, Aris IM, Chong YS, et al. Maternal Protein Intake during Pregnancy Is Not Associated with Offspring. J Nutr 2015;145:1303-10.

19. Aris IM, Soh SE, Tint MT, Saw SM, Rajadurai VS, Godfrey KM, et al. Associations of gestational glycemia and prepregnancy adiposity with offspring growth and adiposity in an Asian population. Am J Clin Nutr 2015;102:1104-12

20. Metzger BE, Lowe LP, Dyer AR, Trimble ER, Chaovarindr U, Coustan DR, et al. Hyperglycemia and adverse pregnancy outcomes. N Engl J Med 2008;358:1991-2002.

21. Berggren EK, Boggess KA, Jonsson Funk M. Population health: modest glycaemic improvements in a pregnant cohort with mild glucose intolerance decreased adverse outcomes. Paediatr Perinat Epidemiol 2014;28:280-6.

22. Asher G, Sassone-Corsi P. Time for food: the intimate interplay between nutrition, metabolism, and the circadian clock. Cell 2015;161:84-92.

23. Schwandt B, de Zwaan M, Jager B. Co-morbidity between type 2 diabetes mellitus and night eating. PPmP 2012;62:463-8.

24. Blais MA, Becker AE, Burwell RA, Flores AT, Nussbaum KM, Greenwood DN, et al. Pregnancy: outcome and impact on symptomatology in a cohort of eating-disordered women. Int J Eat Disord 2000;27:140-9.

25. Stewart DE, Raskin J, Garfinkel PE, MacDonald OL, Robinson GE. Anorexia nervosa, bulimia, and pregnancy. Am J Obstet Gynecol 1987;157:1194-98.

26. Morgan JF, Lacey JH, Sedgwick PM. Impact of pregnancy on bulimia nervosa. Br J Psychiatry 1999;174:135-40.

27. Crow SJ, Keel PK, Thuras P, Mitchell JE. Bulimia symptoms and other risk behaviors during pregnancy in women with bulimia nervosa. Int J Eat Disord 2004;36:220-3.

28. Crow SJ, Agras WS, Crosby R, Halmi K, Mitchell JE. Mitchell, Eating Disorder Symptoms in Pregnancy: A Prospective Study. Int J Eat Disord 2008;41:277-9. 